JURNAL AL BAYAN: JURNAL JURUSAN PENDIDIKAN BAHASA ARAB

p-ISSN 2086-9282 | e-ISSN 2549-1229

\title{
Various Forms and Meanings of Diminutive in Classical and Modern Arabic
}

\author{
Abdul Aziz ${ }^{1}$, Riski Gunawan ${ }^{2}$, Saepul Anwar ${ }^{3}$ \\ ${ }^{1}$ English Linguistic Study Program Universitas Pamulang, Indonesia \\ ${ }^{2}$ Arabic Education Study Program Universitas Islam Negeri Raden Intan Lampung, Indonesia \\ ${ }^{3}$ Arabic Linguistic Study Program Universite Mohammed Premier Oujda, Maroko
}

\author{
Article History: \\ Received : May 5, 2020 \\ Revised : June 15, 2020 \\ Accepted : July 20, 2020 \\ Published : December 01, 2020
}

\section{Keywords:}

Affection; Closeness; Meaning;

Smallness

*Correspondence Address: dosen02345@unpam.ac.id

\begin{abstract}
Diminutive (isim tasgĩr) is often interpreted in Arabic as a word that means 'little'. In fact, linguistic data shows the many meanings denoted and connoted by this diminutive form and meaning. Hence, this study aims to describe various forms and meanings of diminutive lexemes in Arabic. Diminutive is a small form of a word which in Arabic is often referred to as isim tasgĩr. The method which is used is descriptive-qualitative. The source of research data are Arabic dictionaries, poetry collections and novels. The results of this study indicate: first, diminutive in Arabic if it is seen in its form has one morpheme, namely $\mathrm{u}$ ay, with three different realizations depending on the number of consonants of a word, i.e. when the lingual unit (adjective or noun) is minimized consists of three consonants, $u$ ay $i$ when the lingual unit (adjective or noun) is divided consisting of four consonants and $\mathrm{u}$ ay iy, with several omissions of several consonants when the lingual unit both the noun and the adjective are divided into five consonants or more; secondly, it is diminutive in Arabic if it is seen as the meaning that shows affection, closeness, intimacy, insulting or looking down, praising and others. The significance of this research based on the presentation of other meanings which are not only of 'smallness' or 'littleness' of its meaning. This study at least has a novelty about adding other meanings that is broader than just a small meaning in Arabic.
\end{abstract}

\section{Introduction}

Diminutive in Arabic is one of the many complex processes of morphological change. Although all Arabic words can be mapped to three patterns based on the number of consonants, in certain cases, the pattern of changing these words into diminutive form is very complicated. For example, the word kitāb. At a glance, the word can be categorized as a trilateral noun with three consonants $[\mathrm{k}, \mathrm{t}$ and $\mathrm{b}]$. Based on this basis, it can simply be changed into diminutive form following the first pattern of fupayl $(\mathrm{CuCayC})$, then as a rule it becomes kutayb by changing the vowel [i]to[u] and $[\bar{a}]$ to [ay]. But in reality, the diminutive form is not in the form of kutayb, but kutayyib with 
the geminate $[\mathrm{y}]$ that follows the second fuPay?il (CuCayCiC) pattern. From there, then the question arises as to the fact that why kitābare actually composed of three consonants [k, $\mathrm{t}$ and $\mathrm{b}]$ diverted to follow the furay?il pattern (CuCayCiC) and not to follow the furayl pattern (CuCayC).

Another problem also arises in the word mustagfir which consists of six consonants and hence follows the third pattern of fu?ay?iyl (CuCayCiyC) so that when it is changed into diminutive form, there is the reduction of two consonants from mustagfir to mugayfiyr. In that word, the consonants omitted are $[\mathrm{s}]$ and $[\mathrm{t}]$. The problem is then why the second and third consonants are reduced and why can the reduction be carried out on the fourth or fifth consonant. ${ }^{1}$ In addition to the above problems, nouns that have been changed to be diminutive cannot be separated from problems of meaning. Sometimes the meaning of a lexeme after being diminutive has a meaning far different from the original lexeme. Therefore this paper questions two levels of linguistic problems in diminutive formation; first, the problem of morphological change and second, the problem of semantic change.

Based on some of the complexities above, the topic of diminutiveness is very important to study. ${ }^{2}$ There are five special articles that review about Arabic diminutive. First, The Diminutives in The DīwānIbnQuzman: A Product of Their Hispanic Milieu?By Abu Haidar (1989) ${ }^{3}$. Abu Haidar's discussion focused more on the existence of diminutive words in IbnQuzman's poems without paying further attention to his pattern of morphological change. In addition, his findings also emphasized more on Amiyah Arabic vocabulary. While this paper focuses on patterns of change in diminutive Arabic Standard (classic and modern). Besides that, what Haidar presented is nothing more than a small meaning in diminutive form. Further elaboration on its meaning did not receive much attention in his study.

Second, Arabic Morphology: Diminutive Verb and Diminutive Nouns in San'ani

\footnotetext{
${ }^{1}$ This paper tries to answer the diminutive morphological problem above with the basic assumption

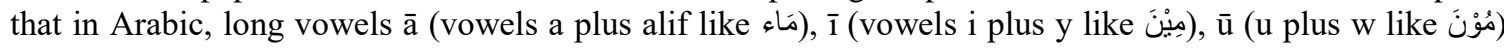
are worth studied furthermore, especially the origin of its formation

${ }^{2}$ To simplify the analysis and presentation, in this paper, the long vowel $\overline{1}$ is transliterated as a combination of $\mathrm{i}$ and consonant y sukun and ai transliterated as ay following Arabic directly, because the

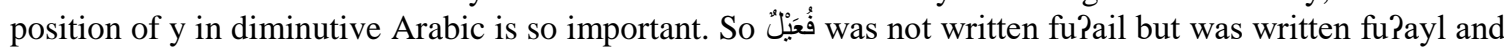
so on.

${ }^{3}$ J.A Abu-Haidar, “The Diminutives in the "Dīwān” of Ibn Quzmān: A Product of Their Hispanic Milieu?," Bulletin of the School of Oriental and African Studies Vol. 52, no. No. 2 (1989) : 239-54.
} 
Arabic by Watson Janet $(2006)^{4}$.Like the previous work, this article reviews the Arabic Amiyah dialect of San'ani, Yemen. One focus of this paper is to discuss diminutive verbs in the San'ani dialect Arabic. Of course the interesting aspect is his findings regarding the number of verbs that are minimized in the amiyah dialect. In fact, diminutive verbs in official Arabic are rarely found except only in interjection sentences and that is also limited to certain verbs.

Third, Default Diminutive: Evidence from Modern Standard Arabic by Sabri Alshboul (2013). ${ }^{5}$ Alshboul studies standard Arabic and emphasizes the formation of feminine pluralistic diminutive Arabic. To conclude, sufix -at as a marker of feminine pluralism is always added to singular, masculine and feminine diminutives and not to plural nouns that are made into diminutive. For example, masculine singular rajul becomes rujayl and is called rujaylāt, not rijāl (plural rajul) becomes rujayyil. Alshboul's research does not explore further the variety of forms and meanings of diminutive lexemes in Arabic. As it will be discussed later, Alshboul is very minimal in data and his review only focuses on the form of diminutive plural. Of course, it is different from the study that is conducted through this paper. The focus of our study is that which has not been touched by Alshboul, which is a matter of the variety of meanings and forms that can be displayed in diminutive ways.

Fourth, A Comparative Study of Diminutive Forms in English and Arabic by Iman Hamid and Sahar Faiq (2009) ${ }^{6}$. This article reviews the comparative dimensions in Arabic and English. The results of the article's research stated that diminutive lexemes in English and Arabic consist of vocabulary, morphological processes and part of speech. This article explains that the pronunciation and meaning of some vocabulary meanings in English and Arabic are similar. English basically uses suffixation and prefix, while Arabic depends entirely on infixation, in which some patterns are basically determined by the morphology of words. Imam Hamid and Sahar Saiq forget that diminutive Arabic experiences a pattern of transfixation, not fixation. Infixation only occurs in one addition while transfixing is the insertion of more than one morpheme simultaneously and of

\footnotetext{
${ }^{4}$ Watson Janet, Arabic Morphology: Diminutive Verb and Diminutive Noun in San'ani Arabic, 2006.

5 Sabri Alshboul, "'Default Diminutive: Evidence from Modern Arabic Standard," Journal of Language Teaching and Research Vol. 4, no. No.1 (2013): 21-26.

6 Iman Hamid dan Sahar Faiq, "A Comparative Study of Diminutive Forms in English and Arabic," Journal of Education and Science Vol. 16, no. No. 1 (2009): 1-15.
} 
course differentiating meaning. So, Faith Hamid and Sahar Faiq are certainly wrong in understanding the morphological processes that occur in Arabic.

Fifth, Noun Diminutive Formation in Algerian Arabic as Used in Jijel: An Optimality Analysis by Samia Azieb (2008). This article analyzes the formation of diminutives in Jijilian Spoken Arabic (JSA), which is an Arabic dialect, and calculates it in the Optimality Theory Framework. The article has revealed that the formation of diminutives in JSA comes from the application of the following phonological processes: vocal syncope, vocal epenesis, vocal shortening, slide insertion, degemination and metathesis. The five articles did not mention in detail the internal structure of changes in diminutive standards in both classical and modern Arabic.

Diminutive itself means the form of words with small meanings, usually with the addition of suffix ${ }^{7}$. The addition of suffixes applies to Indo-European languages such as Dutch -je, French -ette and English -let ${ }^{8}$. In contrast to Indo-European languages, Arabic diminutive is very unique, not using the addition of suffixes at the end of a word that is changed into diminutive form but rather by changing according to certain patterns 9 . Morphological processes of diminutive form in Arabic can be realized in the form of minor fixation or derivation ${ }^{10}$. Actually this process is done by adding affixes to the root of the word to be changed into diminutive form can mean 'small', whether it is used for its literal or metaphorical meaning ${ }^{11}$. Word-formation in Arabic occurs internally, namely by the process of affixation and modification at the root of a word ${ }^{12}$. However, this process does not occur randomly, but rather by following certain patterns which correspond to the morphological structure of the words that can be changed according to diminutive forms.

Arabic uses three patterns (wazan) in the formation of dimunitives; firstly fupayl (CuCayC) pattern, secondly fuPay?il (CuCayCiC), and thirdly,fuPay?iyl (CuCayCiyC). All three patterns are used according to the number of consonants in a word. The first pattern applies to all words consisting of three consonants. For example, the word roqm 'number' consists of three consonants [r, $\mathrm{q}$ and $\mathrm{m}$ ] and when converted to ruqaym 'small

7 H. Kridalaksana, Kamus Linguistik, (Jakarta : Gramedia Pustaka Utama, 2008), 53.

8 F. Katamba. Morphology. (London : Macmillan Press, 2008) 21, 48-49 and 75.

9 Abduh Rojih, At-TațbīqaȘ-Șorfiy (Beirut: Dar Nahdah Arabiyah, 1999), 130.

10 Samih Abu-Mughli, Fiqhu L-LughatiwaQadaya l-Arabiyya (Amman: Majdalawi Press, 1987),

411.

${ }^{11}$ David Crystal, A Dictionary of Linguistics and Phonetics (Oxford: Basil Blackwell Ltd, 2008), 145. 
number'. The second pattern is used for each word consisting of four consonants. For example, the word 'mosque' consists of four consonants [m, s, j and d]. When converted to diminutive, it becomes 'small mosque'. Meanwhile, the third pattern is used for all words consisting of five or more consonants. For example, the word multaklif 'explorer' consists of six consonants. When transformed into diminutive, it becomes a mukay if 'small explorer'. The consonants of $[\mathrm{y}]$ in the three patterns above have an important role in Arabic diminutive and are often referred to as [y] diminutive or yamushoghoroh (the letter ya are written) $)^{13141516 .}$

Based on the pattern of diminutive formation as has been explained by experts above, it can be illustrated that actually diminutive Arabic has only one basic pattern namely $\mathbf{u}$ ay, with three realizations ( $\mathbf{u}$ ay, $\mathbf{u}$ ay $\mathbf{I}$ and $\mathbf{u}$ ay iy) and this is certainly different from the opinions of some experts who divide it into three patterns. The pattern of $\mathbf{u}$ ay becomes $\mathbf{u}$ ay when the lingual unit (adjective or noun) of diminutive form consists of three consonants. The pattern $u$ ay become $\mathbf{u}$ ay $\mathbf{i}$ when the lingual unit (adjective or noun) of the diminutive form consists of four consonants. The $\mathbf{u}$ ay pattern realizes to become $\mathbf{u}$ ay iy with the reducing of several consonants when the lingual unit of both nouns and adjective is consisted of five or more consonants.

So, this study will analyze the data relating to diminutive in the frame that diminutive in Arabic actually only has one form with three different realizations depending on the number of consonants that are in the diminutive. The formulation of the problem can be framed as below; first, what is the form of variant diminutive in Arabic and second, what is the meaning of the form? Does the lexemes being diminutive always contain 'little' in meaning or not?The purpose of this research is to describe diminutive forms in Arabic and present variants of its meaning. In addition, this research also ensures that diminutive in Arabic does not only mean 'small'.

\section{Method}

The object of this research is diminutive lexemes in Arabic. The data is taken from Arabic dictionaries such as Mu'jam al-Lughat al-Arabiyah al-Mu'ashirah, al-

\footnotetext{
${ }^{12}$ Katamba, Morphology (London : Macmillan Press, 2008), 63.

13 Abduh Rojih, At-TațbiqaS-Sorfiy.

${ }_{14}$ Amru Sībawaih, Al-Kitab (Beirut: Dār al-Kutub al-Ilmiyyah, 1999), 460.

${ }^{15}$ Mustafa Al-Ghalayini, "Jami'u d- Durusi 1-“Arabiyya," Vol. 1 (Sayda. Al-Maktabatu l-Asriyya.
} 1971), 87. 
Qomus al-Muhit, Lisan al-Arab, DiwanAbi-Tayyib al-Mutanabbi and Tauq al-Hamamah. The reason of selection of several dictionaries, collections of poems and novels as a source of data is due to that the lexemes are sufficient to collect classical and modern Arabic vocabulary. There are three methods used in this study, namely (1) data collection method, (2) data analysis method, and (3) data analysis results presentation method. The data to be raised is diminutive Arabic patterned with three realizations. Because the study is in the form of written language, in collecting data, it uses the note taking technique, by recording all data in a data card. After the data is collected, then the data is analyzed using the method of distribution using the transforming technique and the referential equivalent method. After the data analysis is complete, the results of the analysis are laid out in the form of a description that will be presented informally in the discussion. It is said to be informal because the results are presented in ordinary words rather than using symbols. However, the author also uses <which means "comes from" and> which means "becomes" and that means formal methods are also used in presenting the results of data analysis in this study. ${ }^{17}$

\section{Result and Discussion}

\section{Arabic Diminutive: An Overview on Forms}

Diminutive triliteral nouns use the $\mathbf{u}$ ay pattern as the first realization of $\mathbf{u}$ ay, namely by adding the vowel $[\mathrm{u}]$ to the first consonant, the vowel [a] to the second consonant, and finally by adding the semivocal[y]. The infixation process is carried out simultaneously. From this pattern, Arabic lexemes consisting of three consonants can be made as diminutive as can be seen in the following examples: (1) nahr 'river'>nuhayr 'small river'. (2) jabalab mountain '>jubayl' hill'. (3) bațn 'belly’>buțayn 'small stomach (masc)'. (4) walad 'child (masc)'>wulayd 'child (masc)'. (5) Ja?r 'hair'> Ju?ayr 'thin hair /' blood vessel'.

From the examples above, it appears that all consonants in examples (1), (2), (3), and (4) have not changed at all. Changes occur precisely in the vowels that is inserted in between the consonants. These changes can be formulated as follows: the vowel in the first syllable become $u$ and the vowel in the second syllable are changed to ay after

\footnotetext{
${ }^{16}$ Wright, William. A Grammar of the Arabic Language. (Cambridge : CUP, 1971), 166.

${ }^{17}$ Sudaryanto, Metodedan Aneka Teknik Analisis Bahasa: Pengantar Penelitian Wahana Kebudayaan Secara Linguistis. (Yogyakarta: Duta Wacana University Press, 1993), 145.
} 
undergoing a diminutive process $(v>\mathrm{u}$ in the penultimate syllable and $\mathrm{a}>$ ay in the ultima syllable). The semivocal position of[y] is very important in the Arab diminutive system because of its position as a reducing marker.If the example above occurs in masculine nouns, the following example occurs in feminine nouns with the addition of the suffix $a h$ at the end of the word: (6) baqar-ah 'cow'>buqayr-ah 'little cow', (7) Jajar-ah 'tree'> Jujayr-ah 'small tree', (8) hujr-ah 'room'>hujayr-ah 'washroom', (9) Jam?-ah 'candle'> Jumay?-ah 'small candle', (10) ḥafl-ah 'party’>ḥufayl-ah 'little party'.

Based on the data above it can be seen that there is no change at all in feminine nouns. That is, the pattern can be likened to masculine gender nouns. However noteworthy, not all Arabic feminine nouns end up with suffixes -ah as in the words $u ð u n$, Payn, sinn, dār andnār. The feminine gender nouns, if changed to diminutive form, should be added to the suffix at the end of the word. For example: (11) uðun 'ears’>uðayn-ah 'small ear', (12) Payn 'eyes'>?uyayn-ah 'small eye', (13) sinn 'teeth'>sunayn-ah 'small tooth', (14) dār 'house'>duwayr-ah 'small house', (15) nār 'fire'>nuwayr-ah 'small fire'. At a glance data no (14) and (15) show inconsistencies in Arabic legal norms that require the need for three consonants for each word to be become changed into diminutive form. But the words $n \bar{a} r^{6}$ fire' and $d \bar{a} r^{\prime}$ house' actually come from nawar and dawar respectively. The consonant [w] disappears when it is enclosed in two vowels of [a] and reappears when changed into diminutive form.

This happens because the Arabs find it difficult (tsiql fi lisan) to pronounce the consonant $[w]$ which is enclosed in two vowels of $[a]$. Because it is so difficult, $[w]$ tends to be silent. From there we can formulate the following rules $[w]>\varnothing / a \_a>\bar{a}$. Another example for this rule can be seen in the following data; (16) qās 'arrows' <qawas, >quwayskecil small arrows ', (17) nāq-ah 'camel' <nawaq-ah, >nuwayq-ah 'small camel', (18) bāb 'door' < bawab, > buwayb 'small door', (19) gār 'cave' < rawar, > guwayr 'small cave', (20) qār-ah 'continent' <qawar-ah, > quwayr-ah 'small continent'.

Diminutive of quadriliteral nouns use the pattern $\mathbf{u}$ ay $\mathbf{i}$ by adding $[\mathrm{u}]$ vowel to the first consonant, vowel[a] in the second consonant, semivocals[y] before the third consonant and vowel [i] before the fourth consonant (CuCayCiC). These additions are carried out simultaneously. More easily it can be seen in the following examples; (21) maktab 'table'>mukaytib 'mini table', (22) mosque 'mosque'> mosque 'small mosque', (23) mablag 'price'>mubaylig 'minimal price', (24) ma?mal 'laboratory'>mu?aymil 'small laboratory'. The examples for feminine nouns can be seen in the following data; 
maqbar-ah 'grave'>muqaybir-ah 'narrow grave', (26) madras-ah 'school'>mudayris-ah 'small school', (27) migraf-ah 'dipper'>mugayrif-ah 'small dipper', (28) mil?aq-ah 'fork'>mulay?aq-ah 'small fork'.

The above pattern is very complex applied to Arabic words with long vowels [i] (as in the word Razīz عزيْ) and long vowels [ā] (kitāb) which are before the final consonant. In the word Pazīz the long vowel [i] $]$ is derived from the combination of vowels [i] with [y] which are obsolete while in the word [kitāb] the long vowels [ā]are derived from a combination of two vowels flanking [w]. So these two words, even though they appear to have only three consonants at first glance, are still regarded as quadriliteralconsonants because there are reduced $[\mathrm{y}]$ and vowel $[\overline{\mathrm{a}}]$. When changed to diminutive form, the two words follow the pattern of $u$ ay $i$ as the realization of $u$ ay for adjective or noun consisting of four consonants (CuCayCiC). (29) Pazīz / Paziyz 'best friend'>Puzayyiz 'little friend', (30) ḥașīr / ḥașiyr 'mat'> hụuṣayyir 'small mat', (31) țarīq / țariyq 'street'>țurayyiq 'small road', (32) d̦arīb-ah / d̦ariyb-ah 'tax'>d̦urayyib-ah 'small tax'. Paziyz consists of four consonants namely [?], [y] and geminated [z] consonant. When changed into diminutive form, vowel $[\mathrm{u}]$ is placed on the first consonant [?], vowel [a] on the second consonant $[\mathrm{z}]$, semivocal[y] before the third consonant [y] and vowel [i] before the fourth consonant [z] so that Paziyz-un becomes ?uzayyiz-un. In this example, we find two consonants of [yy] where [y] is the first affix diminutive and the second $[\mathrm{y}]$ is a phoneme from the origin of the word before it is changed to diminutive form. So are other examples.

As for kitāb (كتاب), the alif comes from the consonant [w], as explained above, the consonant $[w]$ disappears following the rules of $[w]>\varnothing / a \_a>\bar{a}$. But when made into diminutive form, the consonant [w] is raised again. Therefore, (كتاب) become kitawab (كَكََّ). After experiencing a diminished morphological process, (كَتَبَب) become kutaywib (كُتَّْوِب). The consonant [w] which is vocal [i] and preceded by [y] undergoes the process

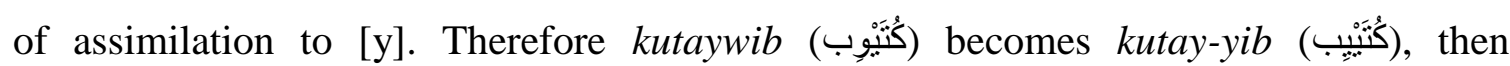
becomes kutayyib (كُنتِب) because there are geminate consonants of [y]. Another example can be explained below; (33) hiizām / hizaam 'belts' < hizawam, > huzaywim>huzayyim 'mini belts', (34) qitāl / qitaal 'war' <qitawal, >qutaywil>qutayyil 'small war', (35) jidār / jidaar 'wall' <jidawar, >judaywir>judayyir 'small wall', (36) risāl-ah / risaal-ah 'letter' <risawal-ah, >rusaywil-ah>rusayyil-ah 'small letter'. 
The process of the emergence of [w] also occurs in Arabic lexemes such as hätif, rākib, nāṣir, kātib, hākim. Like the previous rules, if the lexeme converted to diminutive, then $[\bar{a}]<$ awa. Therefore, the consonant $[\mathrm{w}]$ is raised again, and can be diminutive as in the following data; (37) tājir / taajir 'trader' <tawajir,>tuwayjir 'small trader', (38) fasiq / faasiq 'rat' < fawasiq,>fuwaysiq 'little mouse, (39) nāqid / naaqid 'critic' <nawaqid, >nuwayqid'little critic', (40) kātib / kaatib 'writer' <kawatib, >kuwaytib 'little writer',

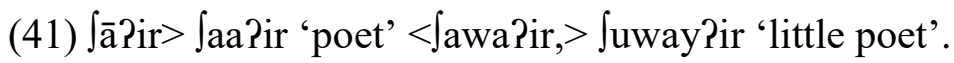

A diminutive lexeme pattern consisting of five or more consonants is actually the same as a quadriliteral diminutive pattern except that the difference lies in reducing one or two consonants and adding [y] before the final consonant. This can be described as follows; First, lexemes consisting of 5 or more consonants are made diminutive in advance according to a quadriliteral diminutive pattern. Second, because it is adapted to a quadriliteral diminutive pattern, then one or two consonants are reduced. Third, adding the consonant y before the final consonant. This can be seen in the following data; (42) farazdaq 'diamond'>furayziq / furaydiq $>$ insertion of affix y (orthographically symbolized by the letter ya '(يْن) y which is not followed by a vowel) before the final consonant, furayziyq $>$ furayzīq / furaydiyq $>$ furaydīq. (43) safarjal 'jewels'>sufayril / sufayrij> insertion of affixes y (orthographically symbolized by the letter ya '(ي ) y which is not followed by a vowel) before the final consonant, sufayriyl / sufayriyj. (44) Pankabūt 'spider'> Punaykib / Punaykit> insertion of affix y (orthographically symbolized by the letter ya'(ي) y which is not followed by a vowel) before the final consonant, Punaykiyb $>$ Punaykīb / Punaykiyt $>$ ?unaykiyt $>$ ?unaykiy $>$ ?unaykiy.

\section{Arabic Diminutive: An Overview on Meaning and Function}

In data no (42), we see the reduction of consonants [d] in furayziyq or consonants [z] in furaydiyq. Data no. 43 is also the case where the fourth or fifth consonant is reduced. This consonant reduction occurs because it follows a quadriliteral pattern which requires a diminutive noun consisting of four consonants while farazdaq and safarjal each consist of five consonants. Therefore farazdaq consists of consonants [f, r, z, d and q] while safarjal consists of 5 consonants [s, f, r, j and l]. After the consonant, the next step is to add [y] as supported by sample of data (1) and (2) above.Because it is adapted to four consonants, lexemes consisting of five or more consonants must be reduced to a few consonants if it is made diminutive. Therefore, if the lexeme consists of five, one consonant is reduced, if it consists of six, only two consonants are omitted. For example, 


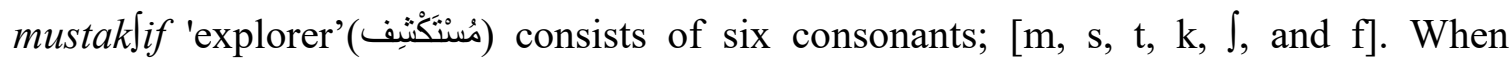
converted to diminutive, the consonants $[\mathrm{s}]$ and $[\mathrm{t}]$ are reduced so that only four consonants such as [m, k, J, and f] forming the lexeme mukaylif (مُكَيْنَفِ). The [y] consonant is added before the final consonant and it becomes reduced to mukaydiyf (مُكَيْنِيْنِف), while [iy] in Arabic becomes umlaut, double vowel [i]], as in the examples of mukayliyf $>$ mukay $\int \overline{1}$.

Diminutive is used to show that something is considered small both in quality and quantity ${ }^{18}$. In its use, diminutive is often used for expressions of affection, intimacy, respect, irritation, humiliation and others ${ }^{19}{ }^{20}$ ). So denotatively, diminutive means little while connotatively depending on the context of its use in sentences. For example, ibn 'child' which is reduced to bunayy, ${ }^{21}$ denotatively means 'little child' and it is often used to express affection (connotatively) as in the following example sentence;

(45) Yābunayy-arkammma?anā (QS. Hud: 42)

(Yā: O: interjection) (bunayy: 'little son’ nom dim sing masc) ( a: pronpos pers1) (irkab: ride: v imperpron pers1 sing) (ma?a: with: adv) (nā: us pron pers1 plural)

'O my beloved son, ride with us!'

The context of this verse speaks of one of the sons of Noah who refused his father's invitation to board the ship when the flood came. Certainly the diminutive bunayy in this verse does not contain the meaning of a child because Kan'an was already an adult at that time. Likewise the word Pax 'brother' becomes uxayy:

(46) Yāîxayy-a jannibilmâ̄ạși

(Yā: O) (?uxayy: little brother: nom dim sing masc) (a: me: pronposs pers1)

(jannib: stay away: v imperpron pers1 sing) (al-ma?āṣi: sins: n plural def N2)

'O My close friend, stay away from the sins!

${ }^{18}$ Muhammad Ali Al-Khuli, A Dictionary of Theoretical Linguistics: English-Arabic with An Arabic-English Glossary. (Beirut: Libraire Du Liban, 1982), 75.

19 A.M. Fontein, Nederlandse Grammaticavoor Anderstaligen (Utrecht: Nederlandse Centrum Buitenlander, 1985), 66.

${ }^{20}$ William Z Shetter, "The Dutch Diminutive," The Journal of English and Germanic Philology Vol. 58, No. 1 (July 1,1959), 75-90..

${ }^{21}$ Pibn (بc) according to Sibawaih is derived from the word [b n w] (بنو). The last syllable aw is omitted and as compensation the syllabus is replaced by $P i$ and placed at the beginning of the word so that it becomes ibn. When it is changed into diminutive, the first process of the word Pibn is returned to its original root, banaw. Then the process is changed into diminutive such as this: Pibn $>$ banaw $>$ bunayw $>$ bunayy. The consonant [w] experiences regressive assimilation to [y] because it is preceded by $[\mathrm{y}]$. 
Diminutive lexeme ?uxayy does not mean here 'little brother'but rather refers to the close relation of the speaker to his friend. The speaker gives advice to his friend who always doesbad things in the eyes of religion. He uses the word $2 u x a y y,{ }^{22}$ not ax to show their closeness and familiarity with the speech partners they advise. Diminutive is also sometimes used to underestimate something. That is, in the eyes of the speaker, something is not important. This can be found for example in the poem al-Mutanabbi.

(47) Yasta?żimūnaubayyāt-anna?amtubihā

(YastaPzim: glorify: $\mathrm{v}$ imperf act) (ūna: they: pron pers3 pluralmasc N1) (ubayyāt-an: stanzas of poetry: $\mathrm{n}$ indef plural N2) (na?am: bored: v perf act) (-tu: I: pron pers1 Sing) (bi: with: prep) (hā: herpronpers3 fem sing)

'They are reciting verses of the poem that I really hate with him'

Ubayyātin the poem of al-Mutanabbi does not mean 'short stanzas' as denoted in their diminutive form. Ubayyatin that context is used to express the attitude of alMutanabbi who despises poetry. An attitude that is inversely proportional to Arabs in general. Another example of this diminutive function can be found in IbnHazm'sTauq alHamamah. When sending a letter to his girlfriend, he uses diminutive lexeme for the purpose of praising the beauty of the lover's face. For example:

(48) “wamā $\int a s r i b t u ~ l-m a \bar{a}$ 'a mina l-kūbiillāwaray?tufïhiwujayhak"

(wa: and: conj) (mā: do not: neg) ( (Jasrib: drink: v perf) (-tu: I: pron pers1 singular ) (l-māPa: n def singular N2 ) (min: of: prep) (al-kūbi: glass: n def singular) (illā: except: conj) (wa: and: conj) (ra?ay: see: v perf) (-tu: I: pron pers1 singular) (fî: in: prep) (hi: her: pronsinggularmasc) (wujayh: face: $\mathrm{n}$ dim sing N2) (your: pronposssingular fem)

'I didn't drink water from a cup of glass but instead I saw the reflection of your face

Wujayh in the example above is not intended to be 'small face' of his lover, but rather intended to praise her beauty, elegance and beauty so that IbnHazm always remembers her every time, until a sip of water that he drinks also reflects his beauty. ${ }^{23}$ Diminutive lexeme is also sometimes used to represent new meaning or new form of a word. The decline of Arabic culture in the last two hundred years and the emergence of

${ }^{22}$ Pax (أخ) according to Sibawaih comes from P x w (أخو). Then it is changed into diminutive form by going through this process ?ax $<$ ?axaw $>$ ?uxayw $>$ ?uxayy.

${ }^{23}$ In line with the above meaning, IbnFarid in his collection of poems, DīwānIbnFarīd, made a

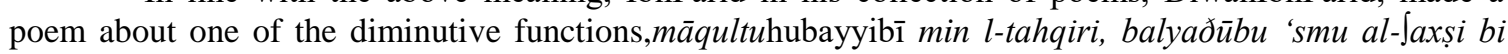


Western culture as the centre of modern civilization enabled Arabic to be influenced by foreign languages, especially English as a language of technology and science. Therefore the process of neology is inevitable. Foreign vocabulary translation projects in various parts of the Arab world are being promoted. Not a few English lexemes have adopted their meanings to be later translated and adjusted into Arabic. ${ }^{24}$

The translation process for certain foreign vocabulary (for example in the fields of anatomy, chemistry, physics and biology) usually uses diminutive. Thus, diminutive contains many meanings (polysemy). On the one hand, it represents the meaning of 'small' with all of its variants. On the other hand it contains new meanings borrowed from concepts that exist in Arabic culture itself or the concept of loans from foreign civilizations. For example the word batn 'belly' is reduced to butayn meaning 'small belly' both in classical and modern Arabic. Other than 'small stomach',butaynalso means 'heart chambers'. 'Heart chambers' are modern meanings borrowed from Western anatomy. Other examples can be seen in the following data: (49) sahl 'plain'>suhayl 'narrow plain' / 'canopus star'. 25 (50) habb-ah 'seeds'>hubayb-ah 'small seeds'/‘zits'. (51) hawawșl-ah 'cache'>huwayṣil-ah 'small cache' / 'festering boils'. (52) bayd 'egg’>buwayḍ-ah 'small egg' / 'ovum'. (53) uðun 'ear'>uðayn-ah 'small ear' / 'hearing instrument'.

From the examples above it can be drawn that diminutive can have a double meaning; first, it contains an objective meaning from the diminutive form of the word in question itself, which means little; Second, it contains other meanings which sometimes have nothing to do with the diminutive lexeme meaning. For example, (49) sahl 'plain' can have the meaning of 'small/narrow plain' and can also mean 'Canopus star'. The

ttasgìri. This poem was translated by Nicholson as follows: Not in contempt I say 'my darling'. No!. By diminution names do sweeter grow (Nicholson via Haydar, 1989, 244).

${ }^{24}$ Once discussed the influence of English on word-formation in Arabic in the journal of Islamic Studies. His findings include the following; First, the addition of lā prefixes to nouns and adjectives such as lāmutanāhī 'infinite ', lāțabaqī'classless', lāiaxlāqī 'immoral', al-lāîurubah 'anti-Arabic', lāțabaqī'not classy', lāiaxlāqī'immoral ', al-lāârubah 'anti-Arabic ', lāma?qūl 'not classy'. Secondly, the use of suffix -at to refer to names of science such as as-sowtiyyāt 'phonetics', iqtișādiyyāt 'economics', lughawiyyāt'linguistics', islamiyyāt 'Islamic science '. Whereas before the 20th century, according to Abderahman, to refer to knowledge, usually the pattern used was the addition of al- and nouns. For example, al-șarf 'morphology', al-handasah 'geometry', al-țib 'medicine', al-tārīx 'history'. Third, the effect is seen in the combination of several lexemes into a dense word (blend). For example bayjuz?iy 'intermolecular' is a blend of baynaplus juz?iy, baysațhiy 'interfacial' is mixing of bayna plus sațhiy, kimmihayawi 'biochemical' is a blend between kimiyā?and hayawiy, kimikahrabiy 'electrochimical' is a blend of bayna plus sațhiy, kimihayawi 'biochemical' is a blend of kimiyā?and hayawiy etc, Abderahman, Wajih Hamad. "A Linguistic Study of The Impact of English on ArabicWord-Formation". Islamic Studies. Vol. 34. No. 2. (1995) : 229-230. 
relation of meaning between narrow plain'and 'Canopus star 'is so far away if it is not said to have no relation at all. Therefore, suhayl is a lexeme which means polysemy which not only represents the meaning of 'narrow terrain' but also represents the meaning of 'Canopus star'.

The rest of the lexeme has a related meaning. For example, we can see the data of (50) habb-ah 'seeds' with hubaybah 'acne', (51) ḥawșal-ah 'cache' with huwayșil-ah 'festering boils', (52) bayd 'eggs'with buwayd-ah 'ovum'. The meaning of the lexeme with its diminutive form can be related to the similarity of the forms referred to by the lexemes. Such a lingual phenomenon can also be called 'metonymy'. Diminutive is also sometimes used to replace classical lexeme which conceptually means relatively the same as the modern form. For example, the meaning of atoms in classical Arabic is expressed through the words al-jauhar al-fard or al-ðarr-ah. The two lexemes are classical Arabic forms that represent the concept of the atom. In the modern age, jusaymwhich is a diminutive ofjism 'body'replaces the position of al-jauhar al-fard or $a l$-ðurr-ah. Thus, these two words are not used anymore. ${ }^{26}$

\section{Conclusion}

From the explanation above, it can be concluded; First, the double vowel $\bar{a}$ is actually a combination of two vowels [a] which surrounds the consonant [w] (orthographically symbolized in the form of alif). Alif itself actually comes from the consonant [w]. In Arabic the consonant [w] suffers when it is flanked by two vowels [a] $(\overline{\mathrm{a}}<\mathrm{aa}<\mathrm{awa})$. This is because the Arabic tongue is very risky if it raises [w] which is flanked by these two vowels. For example kitāb, it is difficult for Arabs to say kitawab so that $[\mathrm{w}]$ is not raised and instead, a vowel is extended. The reduction of the second consonant $[\mathrm{s}]$ and the third consonant of $[\mathrm{t}]$ on the diminutive mustagfir becomes mugayfiyr, mustaklif becomes mukay[iyf because $[\mathrm{s}]$ and $[\mathrm{t}]$ are not the original consonants of mustagfirand mustakjif. It could be said that $[\mathrm{s}]$ and $[\mathrm{t}]$ are infixes from the

${ }^{25}$ The brightest star in the Constellation Carina after Sirius. Usually on December 28-29 this star shines very brightly in Meridian. In Arabic culture, Canopus is also called kawkabyamaniy 'Yemeni star' as a marker of the coming of the fruit season.

${ }^{26}$ At first al -jauhar al-fard or al-ðarr-ah was used by Islamic theologians as an argument or argument to prove the diversity of God's knowledge and as an argument for the novelty of nature. The term was first introduced in the realm of theology by a muktazilah named Abu Hudzail al-Allaf, teacher of Abu al-Hasan al-Ash'ari, founder of the AhlSunnahwa al-Jama'ah school (Al-Jabiri, Muhammad Abid. Bunyat al-Aql al-Arabi: Dirasat Tahlīliyyah Naqdiyyah li Nuḍm al-Ma'rifah fi al-Tsaqōfah al-Arabiyyah. Beirut : 
root words gafara (g, f and $\mathrm{r}$ ) and kalafa (k, $\int$ and $\left.\mathrm{f}\right)$. Whereas the consonant [m] followed by the vowel $[\mathrm{u}]$ does not disappear because it is a marker of the perpetrator, as is the case with the prefix in Indonesian. However, it should also be noted that the reduction of the second consonant $[\mathrm{s}]$ and the third consonant of [t] only applies to pattern ofmustaftafilll. Whereas lexemes other than the pattern, only the fourth or fifth consonant is reduced. This third pattern according to us is still problematic if viewed from the standpoint of meaning. Because the rules that apply in Arabic, if there is reduction of one of the lingual elements of a lexeme, it will certainly change the overall meaning or even have no meaning at all. In addition, another consideration is the fact that diminutive of four consonants in Arabic literature is unproductive. Therefore, to make diminutive form of four consonantal lexemes, we propose the use of a periphrastic paradigm. For example, instead of making diminutive of safarjal to sufayrij or sufayriyl, it is more appropriate to use safarjalsogìr/haqīr which is more meaningful. Second, diminutive in Arabic is often used to show affection, intimacy, insult or look down on, praise and others. It all depends on the meaning of the speaker based on the context behind the speech setting and context.In addition to the pragmatic functions above, diminutive is also used to create a new lexeme (neologism) with a different meaning from that of the diminutive grammatical itself.

\section{Acknowledgment}

We thank as much as possible to Prof.Dr. I DewaPutuWijana, S.U., M.A. who have provided suggestions for the content and substance of this research and also we thank Dr.Suhandano, M.A. which provides us fresh ideas in linguistic research, especially the research on diminutives that we conducted.

\section{References}

Abderahman, Wajih Hamad. "A Linguistic Study of The Impact of English on ArabicWord-Formation”. Islamic Studies. Vol. 34. No. 2. (1995) : 223-231.

Abu-Haidar, J.A "The Diminutives in the "Dīwān" of Ibn Quzmān: A Product of Their Hispanic Milieu?".Bulletin of the School of Oriental and African Studies, Vol. 52. No. 2. (1989) : 239-254.

Markaz Dirasat al-Wahdat al-Arabiyyah, 2009, 180). Then this lexeme became popular among Arab chemists, physics and biologists at that time. 
Abu-Mughli, Samih. Fiqhu l-LughatiwaQadaya l-Arabiyya. Amman : Majdalawi Press, 1987.

Al-Ghalayini, Mustafa. Jami'u d-Durusi l-'Arabiyya Vol.1. Sayda. Al-Maktabatu 1Asriyya, 1971.

Al-Jabiri, Muhammad Abid. Bunyat al-Aql al-Arabi: Dirasat Taḥlīliyyah Naqdiyyah li Nudum al-Ma'rifah fi al-Tsaqōfah al-Arabiyyah. Beirut : Markaz Dirasat alWahdat al-Arabiyyah, 2009.

Al-Khuli, Muhammad Ali. A Dictionary of Theoretical Linguistics: English-Arabic with An Arabic-English Glossary. Beirut : Libraire Du Liban, 1982

Al-Iryani, M. Al-mu'jam al-yamany al-lughat wa-t-turath. Damascus: Dar al-Fikr, 1996.

Al-Rojaie, Y. Diminutives in Najdi Arabic: An account of socio - pragmatic variation. Journal of Human and Administrative Sciences, Vol. 1. No. 2. (2012) : 5-35.

Alshboul, Sabri "Default Diminutive: Evidence from Modern Arabic Standard", Journal of Language Teaching and Research, Vol. 4. No.1. (2013) : 21-26.

Allan, K. and Salmani Nodoushan, M. A. Pragmatics : The State of the Art. International Journal of Language Studies. Vol. 9. No. 3. (2015) : 147-154

An-Nailah, Abdul-Jabbar A. As-Sarfu l-Wadih. Mosul: Mosul University Press, 1988.

As-Sālih, Subhi DirāsātunF̄̄Fiqhi l-Lugha. Beirut: Daru 1-Malaȳ̄n, 1960.

Aziz, Yowell Y. "Modes of Address in English Arabic Translation" Babel, No. 3. Vol. xxx1, (1985) : 144-146.

Badarneh, Muhammed A. The Pragmatics of Diminutives in Colloquial Jordanian Arabic. Journal of Pragmatics Vol. 42. No. 1 (2010) : 153-167

Bat-El, O. Stem modification and cluster transfer in Modern Hebrew. Natural Language and Linguistic Theory. Vol. 12, 571-596.

Bauer, Laurie. Evaluative morphology: in search of universals. Studies in Language Vol. 21 No. 3, (1997) : 533-575.

Benyoucef, R., \& Mahadin, R. Phonological processes in Algerian Arabic as spoken in Mostaganem: An optimality perspective, Research on Humanities and Social Sciences, Vol. 3 No. 14, (2013) : 85-100

Crystal, David. A Dictionary of Linguistics and Phonetics. Oxford. Basil Blackwell Ltd, 2008.

Dahl, O . Diminutives and augmentatives. In K. Brown (Ed.), The encyclopedia of language and linguistics (Vol. 3, 2nd ed. pp. 594-595). London: Elsevier, 2006 
Davis, S., \& Zawaydeh, B. (1999). A descriptive analysis of hypocoristics in Colloquial Arabic. Language and Linguistics, Vol. 3, 83-98.

Dawood, Mohammed. \&Farhan, Zuhair "Aspects of Lexical Development in Modern Standard Arabic "Ādābu- rRāfidayn, Vol. 20, (1989) : 39-52.

Dressler, W., \&Merlini Barbaresi, L. Morphopragmatics of diminutives and augmentatives: on the priority of pragmatics over semantics. In I. Kenesei\& R.M. Harnish (Eds.), Perspectives on semantics, pragmatics and discourse: a festschrift for Ferenc Kiefer (43-58). Amsterdam: Benjamins, 2001.

Fontein, A.M. \&Pescher. A. Nederlandse Grammaticavoor Anderstaligen. Utrecht. Nederlandse Centrum Buitenlanders, (1985).

Fayez, E. Siibawaih's linguistic analysis of the diminutive in Classical Arabic and its subsequent developments (Published doctoral thesis). USA : Georgetown University, (1990)

Gafos, A. I. An argument for a stem-based view of Arabic morphology: doubled verbs revisited. In D. B. Parkinson, \& E. Benmamoun (Eds.), Perspectives on Arabic Linguistics. Vol. 13-14. Amsterdam: Benjamins. (2002) : 59-86.

Hamid, Iman, Sahar Faiq. "A Comparative Study of Diminutive Forms in English and Arabic"Journal of Education and Science, Vol. 16 No. 1, (2009) : 1-15.

Ibrahim, A. Noun formation in Standard English and Modern Standard Arabic: A contrastive study, Journal of Language Teaching and Research, Vol. 1 No. 5, (2010) : 614-623.

Ibrahim, Hisham "Pronouns and Forms of Address in Iraq" Journal of the College of Teachers, Vol. 36, (2003) : 20-32.

Ibrahim, Yousef, "Diminutive in Najdi Arabic : An account of socio-pragmatic variation". Journal of Human and Administrative Sciences. Vol. 1, (2012) : 935

Ismail, A. The diminutive in Modern Standard Arabic: An optimality theoretical analysis, Canadian Social Science, Vol. 8 No. 2, (2012) : 187-196.

Katamba, F. Morphology. London. Macmillan Press, 1993.

Kharma, Nayif \& Hajjaj, Ali. Errors in English Among Arabic Speakers: Analysis and Remedy. London: Longman Group Ltd, 1989.

Kridalaksana, H. Kamus Linguistik. Jakarta. Gramedia Pustaka Utama, 2008.

Laalo, K. Diminutives in Finnish child-directed and child speech: Morphopragmatic and morphophonemic aspects, Psychology of Language and Communication, Vol. 5. No.2, (2001) : 71-80. 
Lahrouchi, Mohammed and Ridouane Rachid. On Diminutive and Plural in Moroccan Arabic. Vol. 26. No.4, (2016) : 453-475

Lee, S. Repair strategies in labial dissimilation: Diminutive formations in Xitsonga, Stellenbosch Papers in Linguistics Plus, Vol 44, (2014) : 89-103.

Maalej, Zouhair. Addressing non-acquaintances in Tunisia Arabic : A cognitive Pragmatic Account”, Intercultural Pragmatic Vol. 7. (2010) : 147-173.

Mahadin, Radwan S. "Noun Diminutive Formation in Algerian Arabic as Used in Jijel: An Optimality Analysis" International Journal of Humanities and Social Science Vol. 5, No. 12 (December 2015).

Mahmood,K M. Eshreteh, A Pragmatic Analysis of Diminutives in Palestinian Society. International Journal of Language Studies. Vol. 11, No. 1. (January 2017) : 4562.

Masliyah, S. The Diminutive in Spoken Iraqi Arabic. Journal of Arabic Linguistic. Vol. $33,(1997): 68-88$.

Nakshabandi, A. Diminutives in Classical Arabic and The Urban Hijazi Dialect. Linguistic Communication Periodical. Vol. 7, (1996) : 1- 15.

Rashid, B.. Optimality of diminutive forms in Modern Standard Arabic, Journal of Basrah Researches (Humanities Series), Vol. 34 No, (2010) : 121-138.

Ratcliffe, R. Prosodic templates in a word-based morphological analysis of Arabic. In M. Eid, \& Ratcliffe R. R. (Eds.), Perspectives on Arabic Linguistics 10. Amsterdam: Benjamins, 1997.

Rojih, Abduh At-TațbīqaȘ-șorfiy. Beirut : Dar Nahdah Arabiyah, 1999.

Salmani Nodoushan, M. A. Review of Philosophical Perspective for Pragmatics. Linguistic Online, Vol. 58. No. 1, (2013) : 119-126

Schneider, K. The truth about diminutives, and how we can find it: Some theoretical and methodological considerations, SKASE Journal of Theoretical Linguistics, Vol 10. No.1, (2013), 137-151.

Shetter, William Z "The Dutch Diminutive". The Journal of English and Germanic Philology. Vol. 58, No. 1 (1 Jan 1959) : 75-90.

Sībawaih, Amru. Al-Kitab. Vol III. Beirut. Dār al-Kutub al-Ilmiyyah, 1999.

Sifianou, M. The Use of Diminutives in Expressing Politeness : Modern Greek vs English. Journal of Pragmatics. Vol. 17, 1992 : 155-173

Sudaryanto. Metode dan Aneka Teknik Analisis Bahasa: Pengantar PenelitianWahana Kebudayaan secara Linguistis. Yogyakarta. Duta Wacana University Press, 1993. 
Taine-Cheikh, Catherine Expressiveness and evaluation in Arabic: the singular development of the diminutive in Hassanniyya Arabic. Studies in Language,John Benjamins Publishing. Vol. 42 No. 1, (2018) : 81-113.

Travis. C. E The Ethnopragmatics of the Diminutives in Conversational Colombian Spanish. Intercultural Pragmatics. Vol.1 No. 2, (2004) : 249-274

Ussishkin, A. P. The inadequacy of the consonantal root: Modern Hebrew and outputoutput correspondence. Phonology, Volume 16, (1999) : 401-442.

Vycichl, Werner Diminutiv und Augmentativ im Berberischen. ZDMG. Vol. III No.2, (1961) : 243-253.

Watson, Janet “Arabic Morphology: Diminutive Verb and Diminutive Noun in San'ani Arabic". Morphology, 2006

Wright, William. A Grammar of the Arabic Language. Cambridge. CUP, 1971.

Wierzbicka, Anna Diminutives and depreciatives: semantic representation for derivational categories. Quaderni di semantica Vol. V, No. 1, (1984) : 123-130

Yassin, M. Aziz F. Personal names of address in Kuwaiti Arabic. Anthropological linguistics. Vol. 20 No.1, (1978) : 53-63.

Al-Andalusi, Ibn Hazm. Tauq al-Hamamah. Beirut : Darul-Kutubi llmiyyah, 2010.

Al-Fayrūzabadi, al-Qāmūs al-Muhịț. Beirut. Daru 1-Kutubi 1-Ilmiyyah, 2009.

Al-Manzur, Ibnu. Lisan al-Arab. Kairo : Dar al-Hadits, 1990.

Al-Mutanabbi, Abi Tayyib. Dìwān al-Mutanabbi. Beirut : Darul-Kutubi 1-Ilmiyyah, 1987.

Ma'luf, Louis. al-Munjid Fi al-Lughati wal I'lam. Beirut : Dar Nahdah Arabiyah, 1990. 